\title{
Metabolism of nitrogenous compounds in the large gut
}

\section{By V. C. Mason, The Grassland Research Institute, Hurley, Maidenhead, Berkshire SL6 ${ }_{5} L R$}

The extent and complexity of nitrogen metabolism in the mammalian large gut (hind-gut) varies considerably between species and is influenced by the physiological age of the animal. It is most highly developed in herbivores and omnivores whose diets, post-weaning, ensure a fairly constant supply of fermentable materials to the lower tract. The present paper reviews some of these topics, with particular emphasis on recent findings in the sheep and pig.

\section{$N$ supply to the large gut}

In both species of animal the amount $(3-18 \mathrm{~g} / \mathrm{d})$ and composition of the ileal $\mathrm{N}$ passing to the hind-gut is related to body size, but the nature and quantity of the feed is also important. In the sheep, for example, this supply is influenced to an appreciable extent $(r 0.74)$ by the duodenal $\mathrm{N}$ flow, while in the pig, the flow of $\mathrm{N}$ and amino acids is affected by dietary $\mathrm{N}$ composition, the type of dietary starch and the passage of fibre (Mason et al. 1976; Sauer et al. 1977a; Taverner et al. I98I). With both classes of animal about half this $\mathrm{N}$ is water-soluble, one-quarter to one-third is soluble in trichloroacetic acid (Ben-Ghedalia et al. 1974; Borgmann et al. 1979; Low, 1979a) and a substantial part (40-80\%) is present in proteinaceous materials of dietary, endogenous and bacterial origin. The contribution of urea- $\mathrm{N}$ is low in the sheep $(<2 \%)$ because of urease activity in the terminal ileum (Clarke et al. 1966; Hecker, $1971 b$ ), but ammonia-N may constitute up to $17 \%$ of this fraction (Clarke et al. 1966; Coehlo da Silva et al. 1972a,b; Hogan, 1973; Ben-Ghedalia et al. 1974). Nucleic acids (Smith \& McAllan, 1971; Coehlo da Silva et al. 1972a,b) and hexosamines (Badawy \& Mackie, s964; Combe et al. 1980) make up $2 \cdot 5-5 \cdot 0$ and $4 \cdot 4-7 \cdot 8 \%$ of this $\mathrm{N}$ respectively in the sheep and calf.

The wall of the large gut supplies $\mathrm{N}$ in the form of urea, mucins and sloughed epithelial cells. In one study (Nolan et al. 1976) urea, which crossed the wall close to or within the caecum of the sheep, provided about $27 \%$ ( $\mathrm{r} \cdot 3 \mathrm{~g} / \mathrm{d}$ ) of the $\mathrm{NH}_{3}-\mathrm{N}$ produced in its lumen, but only $41 \%(2.4 \mathrm{~g} / \mathrm{d})$ of the urea degraded in the digestive tract was metabolized in the rumen and caecum. Presumably much of the remainder $(3.4 \mathrm{~g} / \mathrm{d})$ was degraded by bacteria living in close association with the hind-gut wall, in regions other than the caecum. In the goat, urea influx into the colon increased proportionally with increase in plasma urea concentrations for a particular diet (Engelhardt \& Hinderer, 1976) and, in contrast to the situation in the rumen, the permeability of the colon wall to this compound appears to be only slightly modified by diet (Engelhardt et al. 1978). Little information is currently 
available for the pig, but tentative estimates suggest that almost one-quarter of the $\mathrm{N}$ entering the hind-gut lumen is secreted by the wall in one or other form (Low, 1982). High-fibre diets stimulate the faecal excretion of water-soluble and endogenous $\mathrm{N}$ in the sheep (Mason, 1981) and pig (Bergner et al. 1980; Mason et al. 1982), but it is not clear whether this reflects increased secretion or decreased efficiency of re-absorption. In man the rate of colon-cell replacement is increased considerably by feeding (Stragand \& Hagemann, 1977).

\section{Catabolic processes}

In almost all recorded cases, the ileal flow of $\mathrm{N}$ in the sheep and pig exceeds the corresponding faecal $\mathrm{N}$ excretion, exceptions to this rule occurring only occasionally (Thornton et al. 1970; Low, 1979a). The daily net absorption of $\mathrm{N}$ from the lumen is, however, only $0.4-5.8$ and $\mathrm{I} \cdot 0-6.9 \mathrm{~g}$ respectively, suggesting that the processes of degradation and absorption are largely counteracted by those of anabolism and the secretion and sloughing of $\mathrm{N}$.

Considerable proteolytic, deaminative, decarboxylative and ureolytic activity has been observed in the caecum of the sheep and pig (Fauconneau \& Michel, 1970; Hecker, 1971 $a$; Henderickx \& Decuypere, 1973; Erbersdobler, 1971; Chalmers et al. 1976; Nolan et al. 1976) and in the sheep most hind-gut digestion occurs in the caecum and proximal colon, with only small net changes in $\mathrm{N}$ flow beyond this point (Dixon \& Nolan, 1982). Animal enzymes probably contribute little to these reactions since there is currently no evidence to suggest the secretion of digestive enzymes by the mucosa of the large gut. Furthermore, the activity of trypsin ( $E C$ 3.4.21.4), chymotrypsin ( $E C$ 3.4.21.1) and carboxypeptidase $A\left(E C C_{3.4 .17 .1)}\right.$ is markedly reduced in the terminal ileum of the sheep (Ben-Ghedalia et al. 1974) and in the rat trypsin and chymotrypsin are rapidly destroyed by the hind-gut flora (Borgström et al. 1959; Genell et al. 1976).

Microbial involvement in these processes can be inferred from the large number of viable organisms in hind-gut digesta from the sheep (Mann \& Ørskov, 1973; Bauchop, 1975) and pig (Ledinek, 1970; Koch et al. 1972) and the ability of individual species to metabolize a wide range of nitrogenous compounds (Draser \& Hill, 1974; Wrong et al. 1981), many of which animal enzymes cannot digest. Amino acids can be metabolized by decarboxylation to yield the corresponding amine and carbon dioxide, by deamination to give $\mathrm{NH}_{3}$ and a variety of saturated fatty acids, $\alpha$-keto acids, $\alpha$-hydroxyl acids and unsaturated fatty acids and by fission to produce cyclic compounds, other amino acids, $\alpha$-keto acids and $\mathrm{NH}_{3}$. Furthermore, bacteria can esterify histamine to $\mathrm{N}$-acetyl histamine, convert the diamines putrescine and cadaverine to pyrrolidine and piperidine respectively and open the pyrrolidine ring of proline and the heterocyclic rings of purines and pyrimidines by $N$-dealkylation reactions. Lecithin is degraded to release choline which is further metabolized to trimethylamine, dimethylamine, methylamine and $\mathrm{NH}_{3}$, dimethylamine being the most abundant secondary amine in human urine. Certain species reduce nitrate to nitrite or $\mathrm{NH}_{3}$, these reactions being of significance for the possible nitrosation of such secondary amines as piperidine, 
pyrrolidine and dimethylamine to the corresponding nitrosamines (Drasar \& Hill, 1974; Wrong et al. 1981).

$\mathrm{NH}_{3}$ plays a central role in most catabolic processes of the hind-gut. In the sheep, tracer studies (Nolan et al. 1976) showed that about $65 \%(3 \cdot 1 \mathrm{~g} / \mathrm{d})$ of the total $\mathrm{NH}_{3}$ flux in the caecum $(5.8 \mathrm{~g} / \mathrm{d})$ was derived by degradation of bacterial, endogenous and dietary residues from the upper gut and proteinaceous materials from the wall of the caecum itself. The daily ileal flow of $\mathrm{N}$ was probably $7-8 \mathrm{~g}$. In other work (Mason et al. $198 \mathrm{r} a$ ) infusion of up to $5 \mathrm{~g}$ gelatin-N (with or without added antibiotic (Nebacitin))/d into the caecum of sheep greatly increased blood urea concentrations and the urinary excretion of $\mathrm{N}$ and urea- $\mathrm{N}$, without significantly altering the corresponding concentrations and amounts of hydroxyproline and other amino acids used as gelatin markers. It was concluded that most of the infused $\mathrm{N}$ had been degraded to $\mathrm{NH}_{3}$ and perhaps amines before absorption.

The significance of bacterial and endogenous residues in the nitrogenous materials degraded in the hind-gut can be deduced from several observations. Greatest proportional losses of amino acids in the large gut of the sheep are usually incurred with 2,6-diaminopimelic acid (DAPA), glutamic acid, valine, alanine, proline, threonine, serine, glycine and cyst(e)ine, in that order (Mason \& White, 1971; Coehlo da Silva et al. 1972a,b; Harrison et al. 1973; Hogan, 1973; Ben-Ghedalia et al. 1974; MacRae \& Ulyatt, 1974; Beever et al. 1978), while in the pig the corresponding sequence is found for glycine, glutamic acid, proline, tryptophan, serine, cyst(e)ine and threonine (Holmes et al. x974; Ivan \& Farrell, 1976; Mason et al. 1976; Sauer et al. 1977b; Buraczewska et al. 1979; Low, $1979 b$ ). These losses of DAPA, glutamic acid and alanine in the sheep are entirely or partly due to the metabolism of undigested bacterial residues from the upper tract, the latter constituting possibly $25-50 \%$ of the ileal $\mathrm{N}$. The cell-wall DAPA and muramic acid of rumen bacteria resists digestion in the small intestine but is extensively degraded in the hind-gut of this animal (Mason \& Milne, 1971; Mason \& White, 1971). As components of the peptidoglycan of methanol-grown bacteria, DAPA, glutamic acid and alanine accumulate in the terminal ileum of the preruminant calf but suffer considerable losses in the large gut (Guilloteau et al. 1980). Relatively small amounts of bacterial $\mathrm{N}$ are present in ileal digesta from the pig (Mason et al. 1976).

The hind-gut losses of cyst(e)ine, glutamic acid, glycine, proline, serine and threonine in both species indicate the metabolism of endogenous materials, these amino acids occurring in relatively large proportions in endogenous mucoproteins (Bella \& Kim, 1972; Degand et al. 1972), pancreas secretions (Corring, 1975) and/or bile acids (Low, 1979b) and in ileal digesta collected from pigs given protein-free diets (Holmes et al. 1974; Sauer et al. 1977a; Taverner et al. 1981). In vitro studies show that hind-gut microbes metabolize mucosal compounds in the sheep (Hecker, 1973) and non-ruminant (Juhr \& Haas, 1976) and hexosamines are more extensively degraded in conventional than in germ-free animals (Combe et al. 1980). Possibly $15-40$ and $30-60 \%$ of the ileal $\mathrm{N}$ is contained in endogenous residues in the sheep and pig respectively. 
Metabolism of undigested dietary residues from the upper tract is poorly documented for the sheep and pig, but some of the plant cell-wall $\mathrm{N}$ which disappears between the duodenum and anus of the sheep (Mason, 198I) is probably digested in this region. Maillard complexes formed during the processing and storage of feeds reduce $\mathrm{N}$ digestibility in the small intestine (Finot, 1973; Erbersdobler, 1976), but in the rat the simpler amino acid-sugar products are readily attacked by intestinal microbes (Horn et al. 1968; Erbersdobler et al. 1970; Tanaka et al. 1975; Finot et al. 1977). The same is true for isopeptides formed when proteins are heated, appreciable quantities of aspartyl-lysine and glutamyllysine disappearing in the large gut in this species (Hurrell et al. 1976). In humans suffering from malabsorption of neutral (Hartnup disease; Asatoor et al. 1970; Milne \& Asatoor, 1975) and basic (cystinuria; Hellier et al. 1972; Milne \& Asatoor, 1975) amino acids, hind-gut activity leads to the production of amines and other compounds, many of which are recovered in the urine.

\section{Anabolic processes}

The hind-gut flora probably synthesize their nitrogenous cell components and secretions from simpler molecules such as $\mathrm{NH}_{3}$, amino acids and peptides (Payne, 1975; Nolan et al. 1976), using carbohydrates as the principle energy source. The quantitative significance of these processes is indicated by the presence of $50^{\circ}-78$ and $62-76 \%$ bacterial $N$ in the faecal $N$ of the sheep (Mason, 1969, 1979) and pig (Mason et al. 1976, 1982; Low et al. 1978) and the excretion of 2.4-5.9 and 3. $1-6.5 \mathrm{~g}$ bacterial $\mathrm{N} / \mathrm{kg}$ dry matter intake respectively. In contrast to earlier opinion (Mason, 1969) it now seems that in the sheep this $\mathrm{N}$ is largely assimilated in the hind-gut from materials released by the catabolism of bacterial ghost cells and endogenous and dietary residues. This would explain the similar amino acid composition of faecal bacteria in these species and the net appearance of methionine and other amino acids in digesta during passage through the hind-gut of the sheep (Coehlo da Silva et al. 1972a) and pig (Holmes et al. 1974; Mason et al. 1976; Sauer et al. 1977a,b; Zebrowska et al. 1977a; Just et al. 1981b).

The importance of energy availability for $\mathrm{N}$ assimilation in the hind-gut of the ruminant is illustrated by several studies. Carbohydrate infusion into the caecum of sheep (Ørskov \& Foot, 1968; Thornton et al. 1970) and cattle (Boekholt, 1976) increased faecal $\mathrm{N}$ excretion, mainly through bacterial cell proliferation ( $\emptyset$ rskov et al. 1970; Mason et al. 198 $1 b$ ); urinary $\mathrm{N}$ showing a corresponding decrease (Mason et al. $198 \mathrm{I} b$ ). In the sheep, caecal infusions of starch and pectin produced a greater effect than a more slowly fermented cellulose, but the response to increasing energy supply was curvilinear with no quantitative changes in the pathways of $\mathrm{N}$ excretion when starch infusion exceeded $\mathrm{I} 10 \mathrm{~g} / \mathrm{d}$ (Mason et al. $\mathrm{I} 98 \mathrm{I} b$ ). Raising the level of forage intake increased bacterial $N$ excretion per unit dry matter intake (Mason, 1981). In the pig, replacement of $250 \mathrm{~g}$ maize starch with $250 \mathrm{~g}$ uncooked potato $\mathrm{starch} / \mathrm{kg}$ in semi-synthetic diets gave increases of 23 and $8 \%$ in the faecal excretion of $\mathrm{N}$ and bacterial $\mathrm{N}$ per kg dry matter intake (Mason et al. 1976), whereas substitution of one-third of the cereal in a high-barley 
diet with grass meal stimulated corresponding increases of 60 and $63 \%$ respectively (Mason et al. 1982). In contrast, infusion studies show that although $\mathrm{N}$ excretion in the faeces and urine of pigs can be modified by carbohydrate fermentation in the hind-gut (Zebrowska et al. i980; Gargallo \& Zimmerman, 198I; Misir \& Sauer, 1982) the effects are usually small (Just et al. 1981a; V. C. Mason and co-workers, unpublished results).

The reasons for these different responses to energy supply are probably associated with differences produced in the balance between fermentable nitrogenous compounds and carbohydrates in hind-gut digesta. The relatively high value for $\mathrm{N}$ :readily-fermentable energy sources in ileal digesta from the forage-fed sheep would be expected to encourage a microbial response to extra energy, especially since more $\mathrm{N}$ is provided from the wall of the large gut itself. In the pig, however, this ratio is usually lower because the contribution of bacterial residues to the ileal $\mathrm{N}$ supply is less and much of the undigested carbohydrate at the terminal ileum is in the form of readily-fermentable starch (Keys \& De Barthe, 1974). When the supply of $\mathrm{N}$ from the ileum is low, provision of $\mathrm{N}$ from the wall of the caecum and colon (the main fermentation sites) could be crucial and possibly inadequate for optimal microbial growth. It seems likely that much of the urea-N metabolized by microbes living in close association with the hind-gut wall is rapidly re-absorbed as $\mathrm{NH}_{3}$ and is therefore unavailable to organisms located on feed particles. Furthermore, the influx of urea and other secretions further down the large intestine would be of little benefit to microbes if there were a local deficiency in readily-fermentable energy sources.

\section{Nutritional significance of $N$ metabolism in the large gut}

It appears that $\mathrm{N}$ metabolism in the large gut of the sheep and pig confers relatively little benefit on the $\mathrm{N}$ status of the host. Amino acids may be absorbed from this region but there is little evidence to suggest that the quantities involved are nutritionally very meaningful once microbial activity is established, though active transport of methionine across the wall of the proximal colon of the newborn pig does occur (James \& Smith, 1976). Direct proof that specific amino acids are not absorbed from this organ in significant quantities in the sheep has been obtained using synthetic DAPA (Mason \& White, 1971) and ${ }^{35}$ S-labelled bacterial cyst(e)ine (Judson et al. 1975; Elliott \& Little, 1977). In the pig, infusion of enzymically-hydrolysed casein (Zebrowska, 1975), unhydrolysed heated or unheated casein (Zebrowska et al. $1977 b$; Gargallo \& Zimmerman, 1981), isolated soya-bean protein or lysine hydrochloride (Sauer, 1976) into the terminal ileum of animals given protein-free or low- to medium-protein diets, gave almost complete digestion in the large intestine but poor utilization within the body, as measured by $\mathrm{N}$ balance. When mixed protein, lysine or methionine were infused into the caecum of pigs given lysine- and methionine-deficient diets the effect on $\mathrm{N}$ balance was positive but very small (Just $e t a l$. $198 \mathrm{r} a$ ) and at high rates of infusion much of the infused lysine was excreted in the faeces. $B$ and $K$ vitamins are assimilated and 
excreted in bacterial cells, but little is known of the proportion absorbed in the soluble form (Baker et al. 1950; Henderickx et al. 1964).

Most of the $\mathrm{N}$ is probably absorbed as ammonia (McDonald, 1948; Erbersdobler, I97I), amines being absorbed in smaller quantities (Henderickx \& Decuypere, I973). These materials can serve as $\mathrm{N}$ sources for the synthesis of non-essential amino acids and other compounds in the gut wall and liver; in the ruminant animal, recycled $\mathrm{N}$ may help to support microbial growth in the reticulorumen (Nolan et al. 1976). The latter may have survival value for animals consuming $\mathrm{N}$-deficient diets, but with high- $\mathrm{N}$ feeds absorption of excess $\mathrm{NH}_{3}$ requires the expenditure of energy to convert it to urea for excretion.

An important aspect of $\mathrm{N}$ metabolism in the hind-gut is that it sustains a microbial population actively engaged in the conversion of hygroscopic or osmotically-active materials to absorbable molecules. A feature of digestion in herbivores and omnivores is that passage of the more slowly digested dietary constituents through the small intestine encourages the movement of large amounts of water into the hind-gut (Partridge, 1978), the water containing appreciable quantities of organic compounds and minerals. Metabolism of organic materials assists the absorption of water, sodium and other essential minerals and at the same time provides the host animal with an extra supply of energy in the form of volatile fatty acids (Mason, 1980).

\section{REFERENCES}

Asatoor, A. M., Cheng, B., Edwards, K. D. G., Lant, A. F., Matthews, D. M., Milne, M. D., Navab, F. \& Richards, A. J. (1970). Gut 11, 380-387.

Badaway, A. M. \& Mackie, W. S. (1964). Quarterly fournal of Experimental Physiology 49, $356-364$.

Baker, F., Nasr, H., Morrice, F. \& Bruce, J. (1950). Fournal of Pathology and Bacteriology 62, $617-638$.

Bauchop, T. (1975). Quoted by Ulyatt, M. J., Dellow, D. W., Reid, C. S. W. \& Bauchop, T. (1975). In Proceedings of the $4^{\text {th }}$ International Symposium on Ruminant Physiology, Sydney, pp. I 19-133 [I. W. McDonald and A. C. I. Warner, editors]. Armidale, NSW, Australia: University of New England Publishing Unit.

Beever, D. E., Terry, R. A., Cammell, S. B. \& Wallace, A. S. (1978). Fournal of Agricultural Science, Cambridge 90, $463-470$.

Bella, A. \& Kim, Y.S. (1972). Archives of Biochemistry and Biophysics 150, 679-689.

Ben-Ghedalia, D., Tagari, H. \& Bondi, A. (1974). British fournal of Nutrition 31, $125^{-1} 42$.

Bergner, H., Simon, O. \& Bergner, U. (1980). In Proceedings of the 3 rd EAAP Symposium on Protein Metabolism and Nutrition, Braunschweig, vol. I, pp. 198-206 [H. J. Oslage and K. Rohr, editors]. European Association of Animal Production.

Boekholt, H. A. (1976). Nitrogen metabolism of the lactating cow and the role of gluconeogenesis from amino acids. Doctorate Thesis, Mededelingen Landbouwhogschool, Wageningen. Wageningen: $H$. Veemann \& B. V. Zonen.

Borgmann, E., Kreienbring, F., Meinl, M. \& Wünsche, J. (1979). Archiv für Tierernährung 29, $419-435$.

Borgström, B., Dahlqvist, A., Gustafsson, B. E., Lundh, G. \& Malmquist, J. (1959). Proceedings of the Society of Experimental Biological Medicine 102, 154-1 55 .

Buraczewska, L., Zebrowska, T., Wünsche, J., Hennig, U., Krawielitzki, K., Kreienbring, F., Meinl, M., Borgmann, E. \& Bock, H. D. (1979). Archiv für Tierernährung 29, 437-460. 
Chalmers, M. I., Grant, I. \& White, F. (1976). In Proceedings of the ist International Symposium on Protein Metabolism and Nutrition, EAAP, Nottingham, pp. 159-1 79 [D. J. A. Cole, K. N. Boorman, P. J. Buttery, D. Lewis, R. J. Neale and H. Swan, editors]. London: Butterworths.

Clarke, E. M. W., Ellinger, G. M. \& Phillipson, A. T. (1966). Proceedings of the Royal Society B I 66, 63-79.

Cochlo da Silva, J. F., Seeley, R. C., Beever, D. E., Prescott, J. H. D. \& Armstrong, D. G. (I 972a). British Yournal of Nutrition 28, 357-371.

Coehlo da Silva, J. F., Seeley, R. C., Thomson, D. J., Beever, D. E. \& Armstrong, D. G. (1972b). British fournal of Nutrition 28, 43-6r.

Combe, E., Patureau-Mirand, P., Bayle, G. \& Pion, R. (1980). Reproduction, Nutrition et Développement 20, 1707-1715.

Corring, T. (1975). Annales de Biologie Animale, Biochemie et Biophysique 15, I $15^{-1} 18$.

Degand, P., Gaveriaux, M. \& Havez, R. (1972). Compte Rendu des Séances de la Societe de Biologie, Paris 622-627.

Dixon, R. M. \& Nolan, J. V. (1982). British fournal of Nutrition 47, 289-300.

Drasar, B. S. \& Hill, M. J. (1974). Human Intestinal Flora, pp. 72-102. London and New York: Academic Press.

Elliott, R. \& Little, D. A. (1 977). Australian Fournal of Biological Sciences 30, 203-206.

Engelhardt, W. v. \& Hinderer, S. (1976). In Tracer Studies on Non-protein Nitrogen for Ruminants, vol. III, pp. 57-58. Vienna: International Atomic Energy Authority.

Engelhardt, W. v., Hinderer, S. \& Wipper, E. (1978). In Ruminant Digestion and Feed Evaluation, pp. 4.1-4.12. Hurley: Grassland Research Institute.

Erbersdobler, H. (1971). Zeitschrift für Tierphysiologie, Tierernährung und Futtermittelkunde 27, 21 7-218.

Erbersdobler, H. (1976). In Proceedings of the Ist International Symposium on Protein Metabolism and Nutrition, EAAP, Nottingham, pp. 139-158 [D. J. A. Cole, K. N. Boorman, P. J. Buttery, D. Lewis, R. J. Neale and H. Swan, editors]. London: Butterworths.

Erbersdobler, H., Gunsser, I. \& Weber, G. (1970). Zentralblatt für Veterinärmedzin Ar7, 573-575.

Fauconneau, G. \& Michel, M. C. (1970). In Mammalian Protein Metabolism, vol. IV, pp. $481-522$ [H. N. Munro, editor]. New York and London: Academic Press.

Finot, P. A. (1973). In Proteins in Human Nutrition, pp. 501-514 [J. W. G. Porter and B. A. Rolls, editors]. London and New York: Academic Press.

Finot, P. A., Magnenot, E., Mottu, F. \& Bujard, E. (1977). Proceedings of Alimentation et Travail, Nancey.

Gargallo, J. \& Zimmerman, D. (1981). Fournal of Nutrition 111 , 1 390-1 396.

Genell, S., Gustafsson, B. E. \& Ohlsson, K. (1976). Scandinavian fournal of Gastroenterology II, $757-762$.

Guilloteau, P., Patureau-Mirand, P., Toullec, R. \& Prugnaud, J. (1980). Reproduction, Nutrition et Développement 20, 615-629.

Harrison, D. G., Beever, D. E., Thomson, D. J. \& Osbourn, D. F. (1973). Yournal of Agricultural Science, Cambridge 81, 391-401.

Hecker, J. F. (1971 a). British fournal of Nutrition 25, 85-95.

Hecker, J. F. (1971 $b$ ). British Journal of Nutrition 26, $135^{-145}$.

Hecker, J. F. (1973). Fournal of Agricultural Science, Cambridge 80, 63-69.

Hellier, M. D., Holdsworth, C. D., Perrett, D. \& Thirumalai, C. (1972). Clinical Science 43, $659-668$.

Henderickx, H. \& Decuypere, J. (1973). In Germfree Research, pp. 36I-368 [J. B. Heneghan, editor]. New York and London: Academic Press.

Henderickx, H. K., Teague, H. S., Redman, D. R. \& Grifo, A. (1964). Fournal of Animal Science 23, $1036-1038$.

Hogan, J. P. (1973). Australian Yournal of Agricultural Research 24, 587-598.

Holmes, J. H. G., Bayley, H. S. \& Leadbeater, P. A. (1974). British fournal of Nutrition 32, 479-489.

Horn, M. J., Lichtenstein, H. \& Womack, M. (1968). Fournal of Agriculture and Food Chemistry I6, $74^{1}-745$. 
Hurrell, R. F., Carpenter, K. J., Sinclair, W. J., Otterburn, M. S. \& Asquith, R. S. (1976). British Fournal of Nutrition 35, 383-395.

Ivan, M. \& Farrell, D. J. (1976). Animal Production 23, I I-I I9.

James, P. S. \& Smith, M. W. (1976). Journal of Physiology 262, 151-168.

Judson, G. J., Abdelsamie, R. \& Bird, R. B. (1975). Australian fournal of Agricultural Research 26, 743-749.

Juhr, N. C. \& Haas, A. (1976). Zeitschrift für Versuchstierkunde 18, 206-21 5.

Just, A., Jørgensen, H. \& Fernandez, J. A. (1981a). British fournal of Nutrition 46, 209-219.

Just, A., Jørgensen, H. \& Fernandez, J. A. ( $(981 b)$. Proceedings of the 6th International Symposium on Amino Acids, Warsaw.

Keys, J. E. \& De Barthe, J. V. (1974). Journal of Animal Science 39, 57-62.

Koch, G., Ledinek, M. \& Gieseke, D. (1972). Zeitschrift für Tierphysiologie, Tierernährung und Futtermittelkunde 30, 222-231.

Ledinek, M. (1970). Un:ersuchungen über die Beteiligung von Mikroorganismen am Verdauungsstoffwechsel des Schweines bei Fütterung roher und gedämpfter Kartoffeln. Dissertation Ludwig-Maximilians-Universität, Munchen, $101 \mathrm{pp}$.

Low, A. G. (1979a). British Journal of Nutrition 41, 137-146.

Low, A. G. (1979b). British Journal of Nutrition 41, 147-1 56 .

Low, A. G. (1982). In Physiologie Digestive Chez le Porc, pp. 189-198 [J. P. Laplace, T. Corring and $A$. Rerat, editors]. Paris: INRA.

Low, A. G., Sambrook, I. E. \& Yoshimoto, J. T. (1978). 29th EAAP Annual Meeting, Stockholm.

McDonald, I. W. (1948). Biochemical fournal 42, 584-587.

MacRae, J. C. \& Ulyatt, M. J. (1974). Journal of Agricultural Science, Cambridge 82, 309-319.

Mann, S. O. \& Ørskov, E. R. (1973). Fournal of Applied Bacteriology 36, 475-484.

Mason, V. C. (1969). Journal of Agricultural Science, Cambridge 73, 99- I I 1 .

Mason, V. C. (1979). Zeitschrift für Tierphysiologie, Tierernährung und Futtermittelkunde 41, I 40-1 49 .

Mason, V. C. (1980). In Current Concepts of Digestion and Absorption in Pigs, pp. 1 1 2-129 [A. G. Low and I. G. Partridge, editors]. Technical Bulletin No. 3, NIRD, Reading and HRI, Ayr.

Mason, V. C. (1981). Zeitschrift für Tierphysiologie, Tierernährung und Futtermittelkunde 45, $161-173$.

Mason, V. C., Bech-Andersen, S. \& Narang, M. P. (1981a). Zeitschrift für Tierphysiologie, Tierernährung und Futtermittelkunde 46, $150-164$.

Mason, V. C., Just, A. \& Bech-Andersen, S. (1976). Zeitschrift für Tierphysiologie, Tierernährung und Futtermittelkunde 36, 3 10-324.

Mason, V. C., Kessank, P., Ononiwu, J. C. \& Narang, M. P. (1981b). Zeitschrift für Tierphysiologie, Tierernährung und Futtermittelkunde 45, 174-184.

Mason, V. C., Kragelund, Z. \& Eggum, B. O. (1982). Zeitschrift für Tierphysiologie, Tierernährung und Futtermittelkunde 48, $241-252$.

Mason, V. C. \& Milne, G. (1971). Journal of Agricultural Science, Cambridge 77, 99- I 1 1 .

Mason, V. C. \& White, F. (197 I). Journal of Agricultural Science, Cambridge 77, 91-98.

Milne, M. D. \& Asatoor, A. M. (1975). In Peptide Transport in Protein Nutrition, pp. 167-182 [D. M. Matthews and J. W. Payne, editors]. Amsterdam: Association of Scientific Publishers.

Misir, R. \& Sauer, W. C. (1982). Fournal of Animal Science 55, 599-607.

Nolan, J. V., Norton, B. W. \& Leng, R. A. (1976). British fournal of Nutrition 35, 127-147.

Ørskov, E. R. \& Foot, M. H. (1 968$)$. Proceedings of the Nutrition Society 28, 3I A-32A.

Ørskov, E. R., Fraser, C., Mason, V. C. \& Mann, S. O. (1970). British Fournal of Nutrition 24, $671-682$.

Partridge, I. G. (1978). British Fournal of Nutrition 39, 539-545.

Payne, J. W. (1975). In Peptide Transport in Protein Nutrition, pp. 283-364 [D. M. Matthews and J. W. Payne, editors]. Amsterdam: Association of Scientific Publishers.

Sauer, W. C. (1976). Factors influencing amino acid availability for cereal grains and their components for growing monogastric animals. PhD Thesis, University of Manitoba.

Sauer, W. C., Stothers, S. C. \& Parker, R. J. (1977a). Canadian Journal of Animal Science 57, $775-784$.

Sauer, W. C., Stothers, S. C. \& Phillips, G. D. (1977b). Canadian fournal of Animal Science 57, $5^{8} 5^{-597}$. 
Smith, R. H. \& McAllan, A. B. (1971). British fournal of Nutrition 25, 181-190.

Stragand, J. J. \& Hagemann, R. F. (1977). American fournal of Physiology 233, E208-E21 I.

Tanaka, M., Lee, T. C. \& Chichester, C. O. (1975). Fournal of Nutrition 105, 989-994.

Taverner, M. R., Hume, I. D. \& Farrell, D. J. (1981). British Fournal of Nutrition 46, 149-1 58.

Thornton, R. F., Bird, P. R., Somers, M. \& Moir, R. J. (1970). Australian fournal of Agricultural Research $21,345^{-} 354$.

Wrong, O. M., Edmonds, C. J. \& Chadwick, V. S. (1981). The Large Intestine. Lancaster: MTP Press Lid.

Zebrowska, T. (1975). Rocznik Naukrol Niczych B97, 11 7-123.

Zebrowska, T., Buraczewska, L. \& Buraczewski, S. (1977a). Rocznik Naukrol Niczych B99, $87-98$.

Zebrowska, T., Buraczewska, L. \& Horaczynski, H. (1977b). Rocznik Naukrol Niczych B99, 99-105.

Zebrowska, T., Zebrowska, H. \& Buraczewska, L. (1980). Proceedings of the 3 rd EAAP Symposium on Protein Metabolism and Nutrition, Braunschweig, vol. I, pp. 222-226 [H. ]. Oslage and K. Rohr, editors]. European Association of Animal Production. 